\title{
Development of Tenun Ikat Troso Industrial Center as a Tourist Village in the District of Jepara
}

\author{
Izza Ulumuddin Ahmad Asshofi and Artin Bayu Mukti
}

Faculty of Tourism, Universitas Stikubank

Semarang, Indonesia

Corresponding author: izza.asshofi@gmail.com

\section{ARTICLE INFO}

Received

26 August 2018

Accepted

17 September 2018

Available online

24 September 2018

\begin{abstract}
Troso is a village that was developed by the government of the district of Jepara to be a tourist village. It has the potential of home-based crafts such as weaving which could be developed into industrial centers. However, not all community members realize the potential. The community members don't recognize that Troso is going to be developed as a tourist village. On the other hand, the way the community member doing their business is very ineffective. There is no coordination with other businessmen to accommodate and to control the business. Each entrepreneur is working on their tradition to enrich their own business. One entrepreneur to another is a competitor. For these reasons, the village needs to be developed in order to be efficient for the welfare of all people in Troso. Purpose of this research is to understand the existence of Tenun Ikat Troso industrial center and to evaluate development strategy of Tenun Ikat Troso industrial center as a tourist village in the district of Jepara. SWOT. The results show that (i) Strength Opportunity strategy was focusing on digging deeper of the potency and then wrap them up in a specific brand which will impact on economic sector, (ii) Strength - Threat strategy was focusing on offering the potency of the village to investor to create added value of the village to attract tourists, (iii) Weakness - Opportunity strategy was focusing on building the community awareness of a tourist village plan and the importance of Troso weaving industry association, and (iv). Weakness - Threat strategy was focusing on identifying existing weaknesses of the Troso tourist village and then inviting other stakeholders to get involved in developing the village.
\end{abstract}

Keywords: development; tenun ikat Troso; tourist village

\section{INTRODUCTION}

\section{Background}

Jepara is known as a city of carving since there is a wood carving crafts centers which is famous overseas. Furniture and carving is spread evenly in all districts with their respective expertise. Another advantage of Jepara district is Ikat Troso Weaving (Tenun Ikat Troso). Tenun Ikat Troso skills has already possessed by the Troso residents

http://ojs.unud.ac.id/index.php/eot that originated from legacy: Tenun Gendong (Piggyback Weaving). In 1943, Troso residents began to develop Tenun Pancal (Foot Weaving) and then in 1946 switched into Nonweaving Machine Tools (handloom) until now. A series of exhibitions followed by efforts to improve quality in accordance with market demand, the handicraft industry is increasingly recognized, not only in the domestic but also in the international market. Businessmen rely on the gate market in Bali, Jogjakarta, and Jakarta. 
According to data from the Bureau of Public Relations of Central Java province on the superior potential in the regions, development of Tenun Ikat Troso can be seen from the number of business units reaching 287 pieces and enable to recruit more than 3,700 workers. The value of products produced during the year of 2010 reached more than IDR 269 billion. This figure is estimated to increase if the employers employ workers who are not registered are considered. Now, Tenun Ikat Troso not only found in the village of Troso, but has spread in many other villages in the sub-district of Pecangaan, such as the village of Karangrandu, Pulodarat, Pecangaan Wetan, Ngeling, Sowan Lor, Sowan Kidul, and Dunan. The spread is caused by the limited land owned by businessmen and later the businessmen opened new workshops in another village or the businessmen place their weaving machine in the houses of the workers.

Lack of awareness of Troso villagers is the main problem in development of Troso tourist village. They don't even know that Troso is being directed to be a tourist village. In fact, Troso residents do not welcome visitors warmly when they want to see the original process of weaving in the workshop. Visitors will only be appreciated if they come into the showroom to buy the product. The villagers think that a showing is not a part of business, they just think that only showroom is a place for business. Therefore, the businessmen should creatively organize this tourist attraction of Tenun Ikat Troso and educate the public about the tourist village. Surely, this must be supported by sufficient tourism component and the role of government to realize Troso becoming a village tourist. A tourist village is in line with the direction of national development.

Tenun Ikat Troso industrial center is one concrete manifestation of the creative industries that promote the talent, expertise, and a high artistic value. The phenomenon of the creative industries is not a new thing for the village of Troso which has proven to have an asset of creativity since the first. In matters of creativity, Troso has no doubt. However, the ability and passion to integrate special products created by the businessmen should be utilized in order to create an ideal condition of an industrial center.

http://ojs.unud.ac.id/index.php/eot
Over the last two years, Tenun Ikat Troso industrial center has been developed rapidly (in exports). The Tenun Ikat Troso not only penetrates the domestic market but was able to penetrate the international market; hence, it is not denied when the villagers of Troso continue to show progress fairly quickly. That potential is then developed to build Troso as an attractive tourist village. Strong appeal in the village of Troso become more strategic when it is integrated with cultural attraction and supporting tourist components presented in a structure of a society that blends with the customs and traditions prevailing in Troso.

Recognizing the magnitude of the strategic value and regard to the existing potential of Troso, it is important for Troso to be well planned as a tourist village becoming more interesting for tourists. As a tourist village, it is a form of a creative industrial center of yarn-backed material and supported by tourist objects which have historical values, social and cultural life of Jepara.

\section{Objectives of the research}

The objectives of this research are:

1. To understand the existence of Tenun Ikat Troso industrial center.

2. To evaluate development strategy of Tenun Ikat Troso industrial center as a tourist village in the district of Jepara

\section{LITERATURE REVIEW}

Jepara is known as a city of carving since there is a wood carving crafts centers which is famous overseas. Furniture and carving is spread evenly in all districts with their respective expertise. Another advantage of Jepara district is Ikat Troso Weaving (Tenun Ikat Troso). Tenun Ikat Troso skills has already possessed by the Troso residents that originated from legacy: Tenun Gendong (Piggyback Weaving). In 1943, Troso residents began to develop Tenun Pancal (Foot Weaving) and then in 1946 switched into Nonweaving Machine Tools (handloom) until now. A series of exhibitions followed by efforts to improve quality in accordance with market demand, the handicraft industry is increasingly recognized, not only in the domestic but also in the international market. 
Businessmen rely on the gate market in Bali, Jogjakarta, and Jakarta.

Develop variants of weaving products that can be the uniqueness character of Jepara. Based on Regent Decree of Jepara No. $050 / 105$ of the year of 2015 which states that Troso is declared to be a weaving tourist village, it is expected that all the people of the village of Troso . It is also subsequently supposed to become one of the icons as a Jepara weaving industrial center. In Jepara, Tenun Ikat Troso is an official uniform for civil servants and employees of public enterprises on Wednesday and Friday. This is supported by the decision of the Governor of Central Java which sets Tenun Ikat Troso as uniform on Thursday. In its development, Tenun Ikat Troso experiencing upand down conditions. The most fundamental thing is there is no coordination among the businessmen on the price; selling similar products, but the price discrepancy is high enough. In other word, it's in one area but not centralized. This leads to an unhealthy competition among the businessmen (Wherry, 2005; Biederman, 2008; Walker, 2009).

Tenun Ikat Troso industrial center is one concrete manifestation of the creative industries that promote the talent, expertise, and a high artistic value. The phenomenon of the creative industries is not a new thing for the village of Troso which has proven to have an asset of creativity since the first. In matters of creativity, Troso has no doubt. However, the ability and passion to integrate special products created by the businessmen should be utilized in order to create an ideal condition of an industrial center. Troso is being directed to be a tourist village. Tourist attraction of Tenun Ikat Troso need to be promoted by tourism industry in Jepara in order to develop Tenin Ikat Troso which will become a village tourist. A tourist village is in line with the direction of national development. Tenun Ikat Troso industrial center is one concrete manifestation of the creative industries that promote the talent, expertise, and a high artistic value. The phenomenon of the creative industries is not a new thing for the village of Troso which has proven to have an asset of creativity since the first. In matters of creativity, Troso has no doubt. However, the ability and passion to integrate special products created by the businessmen should be utilized in order to create an ideal condition of an industrial center.

\section{RESEARCH METHOD}

This research is a qualitative approach. It is a qualitative style in which the researcher is as the main instrument of the research, where the researcher as a planner that sets the research focus, selects the informants, as the executor of collecting the data, interpreting the data, taking provisional conclusion in the field and analyzing data in the field in natural setting. Source data used are primary and secondary sources and data retrieval is taken through purposive sampling technique in order to get informants in accordance with its capacity. The technique of collecting data is through interviews, observation, library research, and documentation. To get the validity of the data is done by triangulation.Data are analyzed using reduction techniques, data modeling, and verification of conclusions that continued using SWOT analysis (Rangkuti, 1998; Sugiyono, 2009).

\section{RESULTS AND DISCUSSION}

\section{Identifying Tourism Component of Tenun Ikat Troso Industrial Center}

There are several tourist destinations in Troso that can be beneficial to enhance the added value as a tourist village. Besides the attraction of making Tenun Ikat Troso, tourists can also make a devotional visit to the tomb of Ki Senu and Nyai Senu, and visiting the phenomenal Mosque Jami' Datuk Ampel founded by Mbah Datuk Gurnadi Singorojo in the $16^{\text {th }}$ century.

The four components of tourism are accessibility, attraction, amenities, and ancillary services (Cooper et al., 1993). Based on the data obtained in the field, the accessibility to the village of Trosois about 1.5 $\mathrm{km}$ of Kudus - Jepara highway; that would also help to improve the mobility of the population. In Troso, not commonly found information about tourist village proclaimed by the government. One of the businessmen, Syaikhu, even don't know if there is a government program of Troso as a tourist 
village. "... I've heard this even from panjenengan, Mas. During this time I sell Tenun Ikat Troso yes merchandise only. If there is a tourist village socialization right as a citizen should be known, well socialized. The only official information about Troso is taken from the official web of Tourism and Culture Department of Jepara, http://ticjepara.com.

In accordance of selling tourism packages of weaving process as an attraction to tourists, Abdul Basir as a Troso Headman said, "Tenun Ikat Trosois as a product as well as an attraction. People come to find Tenun Ikat Troso, if they have time they want to see the process of weaving. Ultimately, they then purchase Tenun Ikat for souvenirs."

The meaning of communication, electricity, radio, and television has also been installed by almost every resident house. Lately, the interest of the internet is quite high. Currently, there is only one homestay in Troso, namely Niqira homestay, newly built in early 2015 and now has not completed the process. The homestay is only comprised of two floors with eight rooms without food and beverage service. In Troso, a representative restaurant is unavailable. People can go to a small shop owned by local community. In the mid 2015's has opened a minimarket in Jalan Troso - Bugel.

Trosohas no chamber of tourism to manage the tourist village. Basir admitted that establishing a chamberis not easy, "It's not easy to involve citizens. People take care of the tourist village is usually busy and busy." Therefore, there is still no chamber of tourism till now.

Troso Tourism Component Based on SWOT Analysis

Most of Troso population working on weaving industry; hence, it's good potential to upgrade them in a tourist village.

http://ojs.unud.ac.id/index.php/eot
Table 3.1 Troso Villagers Occupation

\begin{tabular}{|c|c|c|}
\hline No & Occupation & Total \\
\hline 1 & Farmer & 330 \\
\hline 2 & Labor & 386 \\
\hline 3 & Tenun Businessmen & 277 \\
\hline 4 & Public servant & 218 \\
\hline 5 & Tenun worker & 3.746 \\
\hline 6 & Trader & 467 \\
\hline 7 & Stock farmer & 34 \\
\hline 8 & Fisherman & 0 \\
\hline 9 & Mechanic & 6 \\
\hline 10 & Doctor & 5 \\
\hline Total & & 5.469 \\
\hline Source: & $\begin{array}{l}\text { Monography of Troso } \\
\text { September } 2014\end{array}$ & Village, \\
\hline
\end{tabular}

In accordance with the strategy, here are the findings of internal and external conditions combined with the existing tourism components:

Table 3.2 Troso Tourism Component Based on SWOT Analysis

\begin{tabular}{|c|c|c|c|c|}
\hline \multirow[t]{2}{*}{ No } & \multirow[t]{2}{*}{ Tourism Components } & \multicolumn{2}{|c|}{$\begin{array}{l}\text { Internal } \\
\text { Condition }\end{array}$} & $\begin{array}{l}\text { External } \\
\text { Condition }\end{array}$ \\
\hline & & $\mathbf{S}$ & $\mathbf{W}$ & $\mathbf{O}$ \\
\hline 1 & Attraction & & & \\
\hline a) & Site attraction & & & \\
\hline 1) & Interesting destination & $\checkmark$ & & \\
\hline 2) & Comfortable atmosphere & $\checkmark$ & & \\
\hline 3) & Historical place & $\checkmark$ & & \\
\hline b) & Event attraction & & & \\
\hline 1) & MICE & & $\checkmark$ & \\
\hline 2) & Festive & $\checkmark$ & & \\
\hline 3) & Sport tourism & & $\checkmark$ & \\
\hline c) & Natural amenities & & & \\
\hline 1) & Geography and landscape & & $\checkmark$ & \\
\hline 2) & Flora and fauna & & $\checkmark$ & \\
\hline 3) & Health center & & $\checkmark$ & \\
\hline $\mathrm{d}$ & Manmade supply & & & \\
\hline 1) & Historical object & $\checkmark$ & & \\
\hline 2) & Cultural object & $\checkmark$ & & \\
\hline 3) & Religious object & $\checkmark$ & & \\
\hline $\mathrm{e}$ & The way of life & & & \\
\hline 1) & Custom & $\checkmark$ & & \\
\hline 2) & Traditional ceremony & & $\checkmark$ & \\
\hline 3) & Handicraft & $\checkmark$ & & \\
\hline 2 & Accessibility & & & \\
\hline
\end{tabular}




\begin{tabular}{|c|c|c|c|c|}
\hline $\mathrm{a}$ & Transportation & & & \\
\hline 1) & Road condition & $\checkmark$ & & \\
\hline 2) & Transport fare & & $\checkmark$ & \\
\hline 3) & Accessible transportation & $\checkmark$ & & \\
\hline 4) & Transport network & $\checkmark$ & & \\
\hline 5) & Mileage & $\checkmark$ & & \\
\hline 6) & Travel time & $\checkmark$ & & \\
\hline 7) & Nearest terminal & $\checkmark$ & & \\
\hline $\mathrm{b}$ & Information & & & \\
\hline 1) & Street sign/ route & & $\checkmark$ & \\
\hline 2) & Information board & & $\checkmark$ & \\
\hline 3) & Online access & & $\checkmark$ & \\
\hline 4) & Printed media & & $\checkmark$ & \\
\hline 5) & Tourist guide & & $\checkmark$ & \\
\hline 6) & Information center & & $\checkmark$ & \\
\hline 7) & Map & & $\checkmark$ & \\
\hline 3 & Amenities & & & \\
\hline $\mathrm{a}$ & Accommodation & & & $\checkmark$ \\
\hline $\mathrm{b}$ & Shopping center & & & $\checkmark$ \\
\hline $\mathrm{c}$ & Café & & & $\checkmark$ \\
\hline $\mathrm{d}$ & Public facilities & & & $\checkmark$ \\
\hline 4 & Ancillary services & & & \\
\hline $\mathrm{a}$ & Tourism information center & & $\checkmark$ & \\
\hline $\mathrm{b}$ & Travel agent & & & $\checkmark$ \\
\hline $\mathrm{c}$ & Chamber of tourism & & & $\checkmark$ \\
\hline $\mathrm{d}$ & Business association & & & $\checkmark$ \\
\hline
\end{tabular}

Source: Data processed, October 2015

\section{Discussion}

\section{Tourism Component Analysis of Tenun} Ikat Troso

By selling nice package of the original manufacturing process of Tenun Ikat Trosowill allow visitor a unique and phenomenal experience. After having had experience in making Tenun Ikat Troso, tourists certainly do not hesitate to buy Tenun Ikat Trosofor souvenirs. As Yoeti (2007) said that a tourism destination must have something to see, something to do, and something to buy.

The Table 3.2 indicates that attraction is the main strength of Troso. That could be part of the construction phase of tourism as stated by Butler that an attraction will entice investors that can bring travel markets systematically to the development of tourism. In addition, the strength becomes very feasible http://ojs.unud.ac.id/index.php/eot to be developed so it does become more beneficial to society and economic value.

There are two important factors in accessibility, they are transport access and information. In terms of transportation, transport fare is a weakness, but the conditions on the ground indicate that the prices are still affordable. Other factors such as road conditions, the type of accessible vehicle, transport network, the distance from the city center, travel time from the city center, and the nearest terminal are all actually be strengths for Troso. In terms of information, factors like media information, online media, brochures, map, information center, and tour guides are weakness that needs to be solved.

Development in terms of amenities is an activity that takes a long time and endowment funds. Amenities like accommodation have not been developed specifically for tourism purposes. The gate to enter Trosois the only amenity sign of Tenun Ikat Troso.

Ancillary services in a tourist village are meant to facilitate tourism activities. Currently, the existing institution in Trosois the government itself. The hope is that the more advanced country with a turnover and higher profits for the welfare of citizens, but if all businessmen walk alone it is not possible to create an ideal tourist village. Abdul Basir admitted if he had no specific plans related to the development of Tenun Ikat Troso. "Maybe next year we can try. It's not easy to involve the community. We still continue to market Tenun Ikat Troso while supported by Jepara government through the Department of Tourism and Culture to vigorously promote to outside." Basir explained. In this case, the function of ancillary services cannot be said to work in accordance with its role. Cooper et al. (1993) said that if the ancillary services are required for tourist organization to take care of tourism service.

\section{Development Strategy on Tourism Components of Tenun Ikat Troso Industrial Center}

S-O strategies in the development of Tenun Ikat Troso industrial centers as tourist village as follows: exploring the tourism 
potential to be developed into an integrated and well-managed tourist village. By transforming into a tourist village, Troso is expected to increase local economy, to arrange nice packages in making Tenun Ikat Troso with performances that attract tourists, to involve the community in the development of the tourist village in order to create tourism awareness on society.

S-T strategies in the development of Tenun Ikat Troso industrial centers as tourist village as follows: offering the potential of tourism to local governments or private sectors to work on the existing potential to be further developed into an attractive tourist village, learning from other tourist villages which have developed tourism potential on craft, always introducing the tourism potential to the other communities through Jepara people who resettle in other city.

W-O strategy in the development of Tenun Ikat Troso industrial centers as tourist village as follows: building awareness on the importance of associations to operate responsible business, so prices are not easily manipulated by middlemen or other parties; building synergy among businessmen who have capital to invest in working on the development of Tenun Ikat Troso industrial centers as a tourist village; continuing to develop the image of Troso as a tourist village of Tenun Ikat; establishing strategic alliances with various parties of tourism organizers.

W-T strategy in the development of Tenun Ikat Troso industrial centers as tourist village as follows: identifying the weaknesses that exist in order to fulfill the requirement of a qualified tourist village of Tenun Ikat; building awareness to the local communities that tourism cannot be developed alone, tourism must involve many parties (stakeholders) and supported by adequate tourism components; lobbying to the various level of government to excellently develop Tenun Ikat Troso.

\section{Development Program of Tenun Ikat Troso Industrial Center as a Tourist Village}

Seeing the strategy developed in the development of Tenun Ikat Troso Industrial Center as a Tourist Village, it's believed to

http://ojs.unud.ac.id/index.php/eot refer to the uniqueness of this tourist village in terms of cultural tourism or social tourism or rural tourism. It is expected to keep the brand image in public mind that the unique form of Troso tourist village is Tenun Ikat that would be an attractive craft to any traveler.

The following programs can be undertaken by the government and Troso villager to achieve those objectives:

\section{Promoting tourist village program}

Governments can execute policies by issuing regulations related to tourism especially on a tourist village to support its development. This can be done through publications, campaigns, and integrated web of Troso tourist village with the Department of Tourism and Culture and other promotional media.

\section{Developing tourism destination of the tourist village program}

Developing tourism destination should try to change an environment into a better place that attracts attention of tourists. This can be done by promoting tourist packages in making Tenun Ikat Troso from beginning to end where tourists also have to spend the night in Troso (certainly beneficial economically for the community) because the process of making complete Tenun Ikat Troso takes two to three days.

\section{Developing the prominent products of the tourist village program}

It's crucial to keep the standard of Tenun Ikat Troso since it's handmade products. There should be innovation on design and quality maintenance.

\section{Establishing ancillary services of the tourist village program}

It is necessary to establish an ancillary service such a chamberof tourism. The ancillary service can play roles in activities that support the development of tourism such as empowerment of local communities, product prices control, marketing tricks, standardization of products and tourist services, and tourist guide training. 


\section{CONCLUSION AND SUGGESTION}

\section{Conclusion}

Tourism components in the development of Tenun Ikat Troso industrial centers as a tourist village in Jepara have not worked optimally and need to be undertaken by the Troso and Jepara government to manage an attractive tourist village.

Development strategy of Tenun Ikat Troso as a tourist village in Jepara is using combining strategies of the strengths opportunities (S-O), the strengths - threats (S$\mathrm{T}$ ), weakness - opportunities (W-O), and weaknesses - threats (W-T), which are then integrated into programs through promoting tourist village, developing tourism destination of the tourist village, developing the prominent products of the tourist village, and establishing ancillary services of the tourist village.

\section{Suggestion}

Tourism components must be run maximally in order to increase the number of visitors. It's essential to execute development strategies which focused primarily to involve the local community of Troso. Establishing an association or chamber of tourist village in Troso in order to create a harmonious synergy among the businessmen and control responsible business operation.

\section{REFERENCES}

Biederman, P. S. (2008) Travel and tourism: An industry primer. Pearson/Prentice Hall.

Cooper, C. J. et al. (1993) Tourism: Principles and Practice. London: Pitman Publishing.

Rangkuti, F. (1998) Analisis SWOT teknik membedah kasus bisnis. Gramedia Pustaka Utama.

Sugiyono (2009) Penelitian Kualitatif. Bandung: Alfabeta.

Walker, J. R. (2009) Introduction to hospitality. New Jersey: Pearson.

http://ojs.unud.ac.id/index.php/eot
Wherry, F. (2005) 'The "authenticities" of ethnic and tourist arts: meanings and money in village handicraft workshops and small-sized factories'. American Sociological Association.

Yoeti, O. A. (2007) Perencanaan dan Pengembangan Pariwisata. Jakarta: Pradnya Paramita. 